\title{
PERANCANGAN HOT AIR BLOWER PADA CONVEYOR 403-V UNTUK MENCEGAH PENGGUMPALAN IRON ORE PELLET (IOP) PADA DAYBIN 404-F
}

\author{
Nur Cholis ${ }^{1}$, Yosua Sebastian ${ }^{2}$, Fariz Hilman Fauzan ${ }^{3}$, M. Fathuraman Pringgatama ${ }^{4}$ \\ Program Studi Teknik Mesin, Universitas Pembangunan Nasional "Veteran” Jakarta, Jakarta Selatan 1234 \\ Email $^{2}$ : yosua.sbstn97@gmail.com
}

\begin{abstract}
Manufacturing of the Hot Air Blower on the Conveyor 403-V in the Direct Reduction Plant of PT Krakatau Steel can prevent clumping of Iron Ore Pellet with the purpose of reducing maintenance frequency in the Material Handling section. The problem faced by PT Krakatau Steel Maintenance Service Mechanic Division of Material Handling Direct Reduction Plant is the frequent occurrence of Iron Ore Pellet clumping after going through the Cement Coating process before entering the reactor, so that it often causes the system have to shut down when maintenance is being carried out, this is very detrimental to the company because the production of sponge iron pellets is hampered. Clumping is caused by not drying IOP during the Cement Coating process, therefore in this study the author designed the Hot Air Blower. By designing the Hot Air Blower, besides eliminating clumping and reducing maintenance frequency, it can also increase the production of DRI (Direct Reduction Iron) and no need to shut down during maintenance anymore.
\end{abstract}

Kata kunci: Maintenance, Iron Ore Pellet, and Hot Air Blower

\section{PENDAHULUAN}

\section{Latar Belakang Masalah}

Pada era ini, besi baja merupakan bahan logam yang sangat diperlukan dalam keberlangsungan pembangunan, baik dalam sektor prasarana umum maupun sektor industri. Sebagai negara berkembang dalam era industrial, Indonesia memiliki kebutuhan yang tinggi dalam konsumsi baja.

PT Krakatau Steel (Persero) Tbk. Merupakan salah satu perusahaan industri baja terbesar untuk kapasitas produksinya di Asia Tenggara. Untuk itu diperlukan kerja sama yang baik antara semua pabrik didalamnya. Dalam hal ini pabrik Direct Reduction Plant (DRP) juga merupakan bagian yang tidak terpisahkan dalam proses industri ini, karena pabrik DRP ini merupakan proses paling awal dalam rangkain produksi dimana tugasnya adalah memproduksi Besi Spoons dengan kualitas tinggi untuk proses selanjutnya.

Direct Reduction Plant atau Pabrik besi Spons adalah pabrik di Krakatau Steel yang mengolah Iron Ore Pellet (IOP) menjadi Sponge Iron (besi spons). Pengolahan bahan baku bijih besi dalam bentuk pellet menjadi besi spons yang berbentuk pellet juga, dimana hasilnya disebut DRI (Direct Reduction Iron) yang nantinya akan digunakan sebagai bahan baku untuk dilebur di unit produksi SSP ataupun di BSP.

\section{Perumusan Masalah}

DR Plant PT Krakatau Steel terkadang menghadapi permasalahan dalam kegiatan produksi DRI. Berbagai masalah yang dihadapi DR Plant cukup beragam dari berbagai sektor, salah satunya adalah dari sektor Material Handling. Material Handling mencakup dari datangnya IOP ke Stock Yard lalu ke reaktor sampai pada proses Discharge dan penyaluran ke gudang Direct Reduction Iron (DRI).

Permasalahan yang sering terjadi di sektor Material Handling salah satunya adalah menggumpal atau menempelnya IOP yang sudah dilapisi semen pada Iron Ore Day Bin maupun pada proses Charge ke reaktor. Seharusnya setelah IOP melalui proses Cement Coating, IOP tidak saling menempel satu sama lain melainkan masing-masing butiran pellet sudah kering terlapisi semen.

Permasalahan yang terjadi adalah tidak maksimalnya pada saat proses Cement Coating. $I O P$ yang sudah dilapisi semen ditransfer melalui Conveyor menuju Iron Ore Day bin ini harusnya sudah dalam keadaan kering, namun pada lapangan $I O P$ masih dalam keadaan basah. 


\section{Batasan Masalah}

Sebagai batasan dalam pembahasan agar tidak terlalu luas dan menyimpang dari permasalahan, maka ruang lingkup penelitian ini dibatasi sebagai berikut:

1. Penelitian dilakukan pada divisi Direct Reduction Plant PT Krakatau Steel (Persero) Tbk.

2. Penelitian lebih dikhususkan lagi pada seksi Mechanic Material Handling DR Plant.

3. Analisa di lakukan pada optimalisasi proses Material Handling mulai dari Cement Coating IOP sampai IOP masuk reaktor.

4. Seluruh Design, Part, dan simulasi dikerjakan menggunakan Software SolidWorks 2016.

5. Tidak memperhitungkan biaya.

\section{Maksud dan Tujuan}

Dari latar belakang dan perumusan masalah yang telah penulis sampaikan maka dimaksudkan:

1. Sebagai masukan bagi perusahaan yang berguna untuk meningkatkan kualitas kerja perusahaan.

2. Untuk melancarkan proses Material Handling, terutama dari proses Cement Coating sampai IOP masuk Iron Ore Day Bin.

3. Untuk Mencegah adanya penggumpalan $I O P$ yang sudah di Coating pada Day bin, sistem Charge, dan sesama IOP dalam reaktor.

4. Untuk menguramgi frekuensi Maintenance karena adanya penyumbatan akibat penggumpalan $I O P$.

\section{TINJAUAN PUSTAKA}

\section{Pengertian Umum Maintenance}

Produksi yang dilakukan oleh sebuah perusahaan selalu memiliki target tersendiri yang dijadikan tujuan utama oleh pabrik pada perusahaan tersebut, sehingga untuk tujuan itu diperlukan unit penunjang kelancaran produksi. Untuk menjamin kelancarannya, maka diperlukan perawatan pada peralatan atau maintenance agar peralatan yang digunakan selalu dalam kondisi siap operasional.

Pengertian maintenance itu sendiri adalah sebuah kegiatan yang bertujuan untu menjaga peralatan agar selalu berfungsi dengan baik dan untuk menjaga delivery time dari produk agar dapat berfungsi secara optimal dalam jangka waktu tertentu. Dalam mencapai tujuan maintenance itu sendiri, aktivitas yang dilakukan maintenance adalah:
1. Aktivitas peningkatan yang berusaha dan bertujuan untuk mempertahankan kehandalan peralatan pabrik.

2. Aktivitas maintenance itu sendiri yang bertujuan untuk mencegah kerusakan atau memperbaikinya.

\section{Jenis-jenis Maintenance}

Kegiatan maintenance yang dilakukan di PT Krakatau Steel (Persero) Tbk. dibedakan atas tiga macam, yaitu:

\section{a. Breakdown Maintenance}

Breakdown Maintenance atau biasa juga disebut Corrective Maintenance diartikan sebagai kegiatan perbaikan dan penggantian komponen mesin yang dilakukan setelah terjadinya kerusakan atau masalah pada mesin sehingga mesin tidak dapat berfungsi dengan baik. Jadi dalam hal ini kegiatan Breakdown Maintenance ini sifatnya tidak dapat diperkirakan, karena kerusakan baru diketahui saat itu terjadi gangguan, baru kemudian dilakukan perbaikan. Dengan demikian, apabila Maintenance yang dilakukan hanya Breakdown Maintenance, maka terdapat faktor ketidakpastian dalam kelancaran proses produksi dan maintenance akibat ketidakpastian akan kelancaran bekerjanya fasilitas atau peralatan produksi yang ada.

Jenis maintenance ini juga memerlukan biaya pemeliharaan yang paling besar. Hal ini dikarenakan selain perbaikan akan menghentikan proses produksi secara tidak terencana, Breakdown Maintenance ini juga memerlukan waktu penyediaan spare part yang banyak karena kerusakan yang ada tidak diprediksi sebelumnya. Biaya yang diperlukan akan lebih tinggi bila spare part yang dibutuhkan adalah spare part yang harus diimpor dari luar negeri.

\section{b. Preventive Maintenance}

Pemeliharaan preventif mengacu pada waktu (time base), terdiri dari kegiatan inspeksi yang dilaksanakan secara periodik untuk menemukan perkembangan keausan pada komponcn atau sub-sistem. Bila ditemui perkembangan keausan yang berpotensi mengancam kinerja alat, kegiatan pemeliharaan akan dilakukan untuk meniadakan dan memperbaiki masalah tersebut.

Kegiatan pemeliharaan korektif bisa dilaksanakan seketika pada saat inspeksi, bisa juga beberapa waktu sesudahnya. Keputusan untuk melakukan pemeliharaan korektif dalam hubungannya dengan inspeksi dan pemeliharaan preventif tergantung pada panjangnya waktu shutdown yang diperlukan untuk keperluan reparasi. Harus dipertimbangkan dampak dari shutdown pada operasi dengan berapa lama waktu reparasi yang diperlukan. Bila telah 
diputuskan bahwa komponen yang aus masih mungkin dipakai sampai reparasi selanjutnya bisa dijadwalkan, lebih baik menunda reparasi kecil ini hingga kegiatan seluruh maintenance dapat dilakukan pada saat reparasi besar selanjutnya dilakukan.

Untuk menentukan interval inspeksi, riwayat pemeliharaan alat tersebut perlu dipelajari. Pengambilan keputusan untuk menjadwalkan inspeksi pemeliharaan preventif bisa dipertimbangkan dari berbagai faktor, seperti rekomendasi pabrik pembuat, informasi balik dari Breakdown Maintenance dan pengetahuan subyektif personil pemeliharaan yang berhubungan langsung dengan alat tersebut.

Pemeliharaan preventif memiliki sifat utama yaitu saat banyak alat yang dipelihara harus shutdown untuk keperluan inspeksi. Proses inspeksi bisa mengakibatkan downtime pada sebagian atau seluruh alat. Kehilangan waktu operasi pada pemeliharaan preventif yang diterapkan secara konsekuen, bisa mengakibatkan kegagalan program kegiatan pemeliharaan preventif itu bila terdapat tuntutan kapasitas operasi 100\%. Pada beberapa situasi, shutdown bisa berakibat kerugian sehingga inspeksi pemeliharaan preventif tertunda.

Kebutuhan down time selama inspeksi pemeliharaan preventiv bukan merupakan alasan untuk menganggap pemeliharaan preventiv tidak efektif. Penerapan pemeliharaan preventiv secara konsekuen akan meningkatkan reliability alat dan pengurangan breakdown memang memerlukan biaya. Biaya pemeliharaan timbul akibat kehilangan waktu produksi pada saat kegiatan inspeksi disebut Waktu Rata-rata untuk Pemeliharaan Preventiv (Mean Time of Preventive Maintenance, MTPM). Total biaya pada pemeliharaan preventif sama dengan MTPM ditambah biaya pekerja dan material yang dibutuhkan dalam kegiatan inspeksi tersebut.

\section{c. Predictive Maintenance}

Pemeliharaan prediktif dikenal sebagai pemeliharaan dengan acuan kinerja atau kondisi alat. Metode ini mengukur setiap keluaran pada alat yang berhubungan dengan kemunduran kualitas komponen ataupun sub-sistem. Misalnya kelelahan logam pada alur unsur bearing. Amplitudo getaran yang dihasilkan oleh unsur putar saat melalui permukaan yang mengalami kemunduran merupakan petunjuk derajat keausan yang terjadi. Pada saat terjadi kemunduran amplitudo getaran akan mengalami peningkatan. Pada beberapa nilai yang kritis analis getaran menyimpulkan perlunya penanggulangan korektif harus dilakukan sehingga kegagalan alat bisa dihindari.
Metode ini biasanya memungkinkan pengukuran yang dilakukan dibandingkan dengan suatu nilai batas tertentu, atau ditelusuri menggunakan kartu kontrol. Bila kondisi abnormal bisa dideteksi, masih tersedia cukup waktu untuk manganalisis kondisi gangguan dan menghindari terjadinya breakdown. Masih ada kesempatan merencanakan penanggulangan ataupun mengurangi dampak kegagalan yang akan terjadi pada alat. Dengan kondisi demikian akan memungkinkan alat beroperasi bebas dari gangguan. prediktif:

Keuntungan penerapan pemeliharaan

- Kegiatan inspeksi bisa dilakukan tanpa menghentikan operasi alat. Dengan demikian tidak adakehilangan waktu akibat inspeksi shutdown.

- Biaya pekerja lebih rendah dibandingkan dengan pemeliharaan preventif. Sekalipun kemampuan teknisi yang diperlukan lebih tinggi, namun waktu yang diperlukan untuk melakukan inspeksi sangat jauh berkurang.

- Alat tidak perlu dibongkar untuk keperluan inspeksi. Dengan menggunakan analisis getaran, 50 sampai 60 alat bisa diinspeksi dalam satu hari dengan bantuan komputer.

- Bila kita bandingkan keuntungan biaya pemeliharaan prediktif terhadap pemeliharaan preventif, pertimbangkan biaya produksi yang hilang akibat down time alat, biaya pekerja pemeliharaan, biaya material pemeliharaan dan biaya inventori, pemeliharaan jenis prediktif ini memiliki biaya terendah.

\section{PENGAMBILAN DATA}

Peralatan penunjang proses Cement Coating antara lain:

\section{Belt Conveyor}

Belt Conveyor berfungsi untuk menyalurkan IOP ke tempat yang dinginkan. Pada cement coating digunakan dua belt conveyor, yaitu $402-\mathrm{V}$ dan $403-\mathrm{V}$ yang mana keduanya memiliki kapasitas 600 ton/h dan kecepatan $1.68 \mathrm{~m} / \mathrm{s}, 402-\mathrm{V}$ memiliki panjang $192 \mathrm{~m}, 403-\mathrm{V}$ memiliki panjang $115 \mathrm{~m}$, dan kedua belt conveyor ini digerakan dengan motor listrik.

2. Water Spray

Water spray berfungsi untuk menyemprotkan air pada IOP agar semen dapat melapisi IOP dengan baik. 
3. Silo

Silo adalah tempat penyimpanan semen sebelum ditaburkan pada IOP, pada DR Plant terdapat dua silo. Banyak semen yang digunakan pada cement coating ini idealnya adalah, tiap 1 ton $I O P$ digunakan $2.5 \mathrm{~kg}$ semen, tetapi pada prakteknya di lapangan saat ini tiap 1 ton $I O P$ digunakan $4 \mathrm{~kg}$ semen.

\section{Cement Feeder}

Cement feeder berfungsi untuk menaburkan semen pada IOP. Semen yang keluar dari silo disalurkan melalui bagian ini lalu dijatuhkan ke 402-V belt conveyor.

\section{Dolomite Tank}

Dolomite tank adalah tempat penyimpanan dolomite. Dolomite ini merupakan inovasi terbaru pada proses cement coating yang memiliki fungsi sama seperti semen yaitu untuk melapisi IOP agar tidak saling menempel, persentase perbandingan penggunaan semen dengan dolomite adalah $70 \%$ $30 \%$.

\section{Snake Head/Mixer}

Snake Head/ Mixer bagian ini berfungsi untuk mencampur IOP dengan semen agar seluruh bagian $I O P$ terlapisi semen secara merata.

\section{Tower T3}

Tower T3 adalah transfer tower yang berfungsi untuk memindahkan IOP dari $402-\mathrm{V}$ ke 403-V belt conveyor. Tower ini memiliki panjang $5500 \mathrm{~mm}$, lebar $5000 \mathrm{~mm}$, dan tinggi $17000 \mathrm{~mm}$.

\section{Iron Ore Day Bin (404-F)}

Adalah tempat penyimpanan IOP sementara, sebelum disalurkan ke reaktor. Iron Ore Day Bin menerima IOP dari 403-V belt conveyor, 404-F ini memiliki diameter $9000 \mathrm{~mm}$, tinggi $20500 \mathrm{~mm}$, dan mampu menampung IOP sebanyak 2000 ton.

\section{HASIL DAN PEMBAHASAN}

\section{Solusi}

Berdasarkan permasalahan yang sudah disebutkan diatas, dapat disimpulkan bahwa letak permasalahannya adalah IOP yang masih terlalu basah. Oleh sebab itu, solusinya adalah dengan menambahkan rangkaian alat pengering $I O P$ berupa Hot Air Blower yang nantinya digunakan untuk membantu proses pengeringan IOP yang sudah di Cement Coating.

Rangkaian alat pengering $I O P$ adalah alat dan juga mekanisme yang bertujuan untuk mengeringkan Iron Ore Pellet yang telah disemprot air dan dilapisi semen saat menuju day bin, sehingga memaksimalkan kinerja dari Material Handling khususnya di bagian Cement Coating sampai day bin yang hasilnya adalah berkurangnya bahkan tidak ada lagi IOP yang menempel di dindingdinding day bin dan reaktor sehingga gangguan dan juga pemeliharaan yang dilakukan menjadi berkurang. Berikut adalah desain gambar dari rangkaian alat pengering $I O P$ yang sudah dirancang.

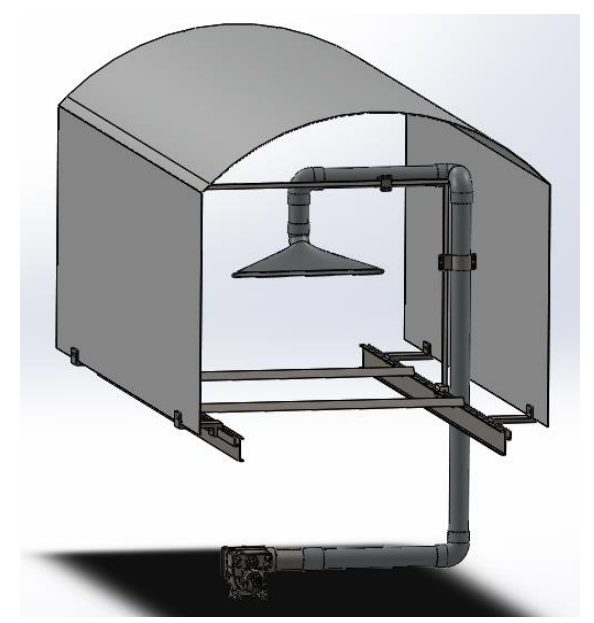

Gambar 1 Rangkaian Alat Pengering IOP

Dari gambar rangkaian alat pengering $I O P$ yang sudah didesain, dapat dijabarkan komponenkomponen apa saja yang digunakan dalam rangkaian alat pengering $I O P$ tersebut, tersaji dalam Tabel 1.

\section{Penjelasan Komponen Alat Pengering IOP}

Untuk komponen yang ada pada rangkaian alat ini dibedakan menjadi dua kelompok, yaitu komponen yang dibuat sendiri dan komponen yang didapat dari supplier. Berikut adalah penjelasan dari masing-masing kelompok komponen beserta spesifikasinya:

\section{Komponen dibuat sendiri}

Komponen yang dibuat sendiri merupakan komponen yang tidak diproduksi oleh supplier secara massal. Adapun komponen yang dibuat sendiri antara lain:

$>$ Stand Penyangga (Part Number 10 dan 11)

Stand penyangga terbagi dua jenis, antara lain Stand penyangga atas horizontal (Part Number 11), serta Stand penyangga vertikal yang posisinya berdiri (Part Number 10). Stand penyangga ini berfungsi untuk tempat utama meletakan komponen seperti pipa besi, nozzle, dan penyangga pipa. 
Tabel 1 Tabel Part Number

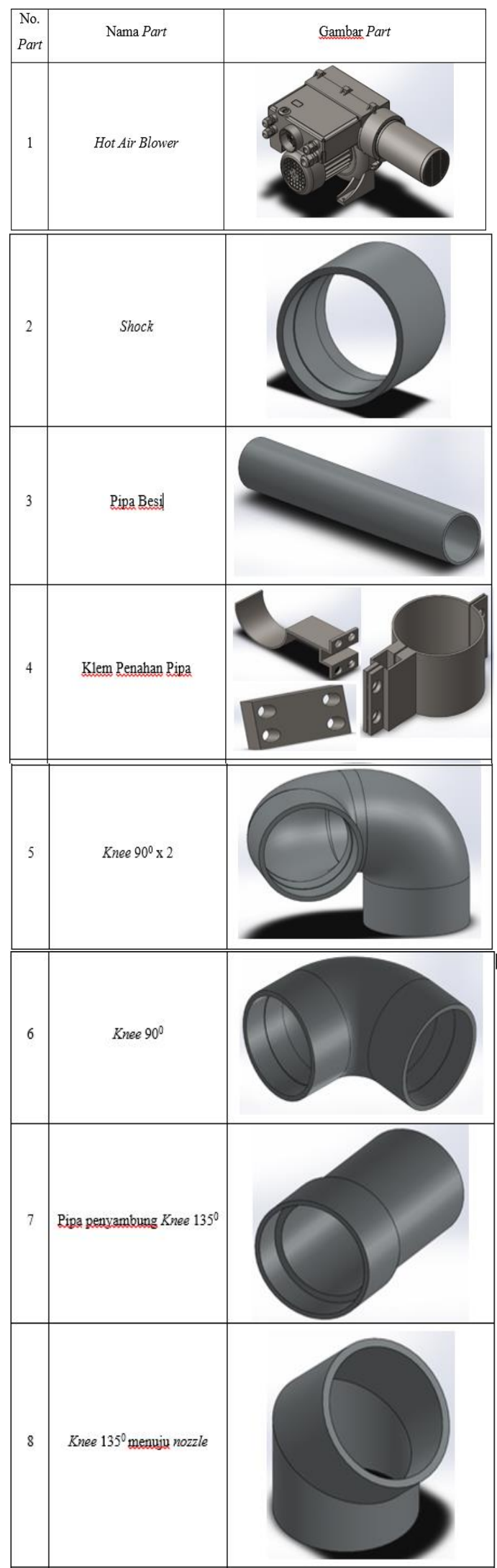

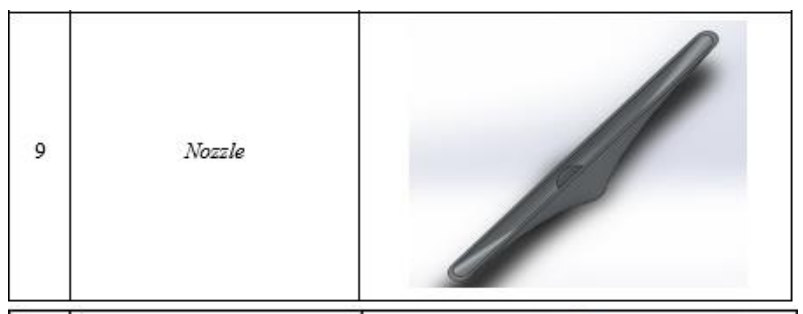
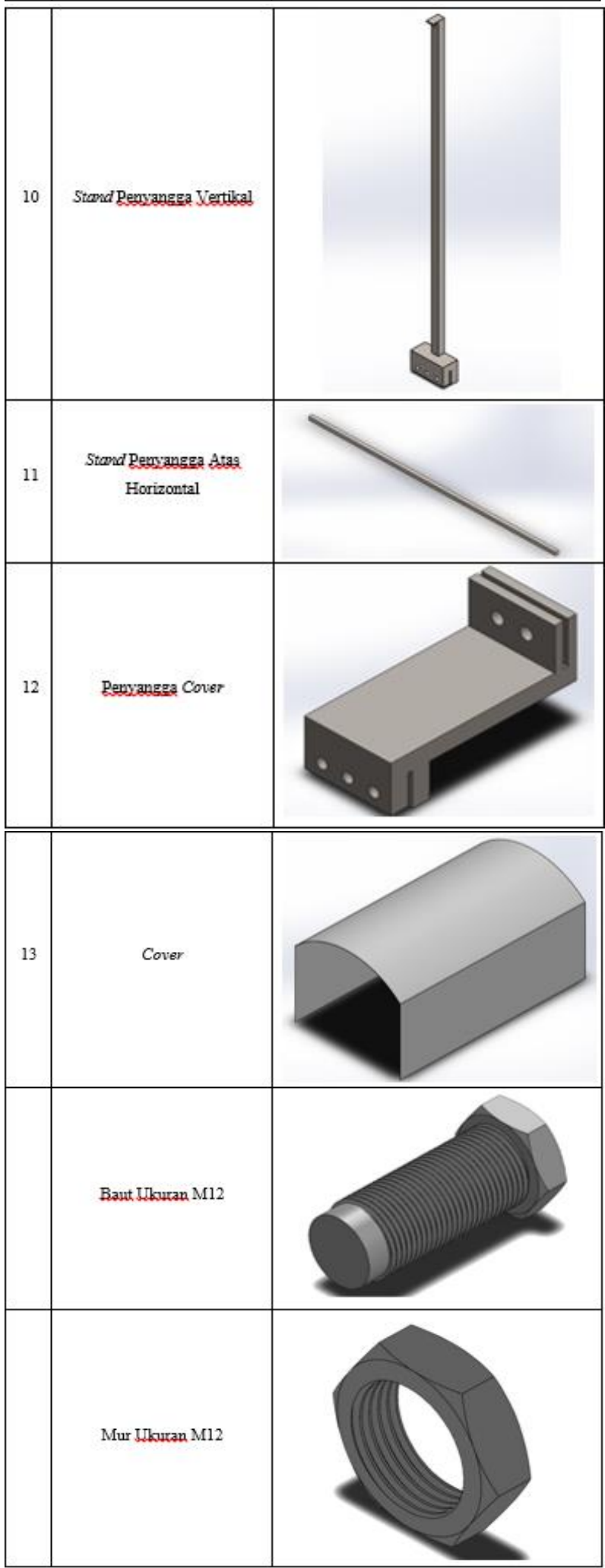
Proses pembuatan Stand penyangga dapat dibuat dengan teknik pengelasan pada sambungan penyangga vertikal dengan penyangga horizontal. Material yang digunakan untuk pembuatan Stand penyangga ini adalah Carbon Steel agar kuat dan ringan mampu menopang pipa besi serta nozzle.

$>$ Klem Penahan pipa (Part Number 4)

Klem yang berjumlah dua ini berfungsi sebagai penahan pipa agar tidak bergerak-gerak dari stand. Berdasarkan posisinya, klem penahan pipa dibagi menjadi dua, yaitu Klem bagian atas (horizontal) dan bagian samping (vertikal). Klem vertikal berfungsi menahan pipa naik dengan Stand penyangga vertikal, sedangkan klem horizontal berfungsi menahan pipa atas dengan Stand penyangga horizontal. Pipa dapat ditahan dengan cara menjepit pipa lalu dikunci ke Stand menggunakan baut dan mur.

Proses pembuatan klem ini adalah dibuat dengan teknik pengelasan dari beberapa potongan besi pejal dan plat besi yang dibentuk sesuai desain, dan teknik drilling untuk membuat lubang baut. Adapun material yang digunakan adalah Carbon Steel yang tahan terhadap karat karena posisinya berada di luar dan memiliki fungsi menopang pipa, khususnya pada klem bagian atas.

$>$ Pipa penyambung Knee $135^{\circ}$ (Part Number 7)

Pipa ini dibuat sendiri karena bentuk yang diinginkan tidak terdapat pada pipa yang disediakan oleh supplier, pipa penyambung ini memiliki fungsi sebagai sambungan antara Knee $135^{\circ}$ dan Knee $90^{\circ}$ di tengah, yang memiliki bentuk seperti Shock pada salah satu sisinya sehingga dapat disambung dengan Knee $135^{\circ}$ (Part Number 8) menggunakan las.

Proses pembuatannya adalah dengan menggabungkan pipa besi yang telah diperoleh dari supplier lalu dilas dengan shock pada salah satu sisi pipa. Material komponen ini mengikuti material pada shock dan pipa besi.

\section{$>$ Nozzle (Part Number 9)}

Nozzle berfungsi sebagai outlet udara panas yang melewati pipa besi untuk disemprotkan kearah IOP yang lewat diatas conveyor. Desain Nozzle ini dibuat sendiri karena menyesuaikan dengan lebar penampang belt conveyor.

Proses pembuatan nozzle ini dengan metode casting yaitu dengan cara melelehkan logam lalu dituangkan kedalam cetakan yang sudah dibentuk sesuai dengan desain yang sudah ditentukan. Material untuk komponen ini adalah Stainless Steel 304L.

\section{$>$ Penyangga Cover (Part Number 12)}

Komponen ini dibuat sendiri karena desain yang dimiliki komponen ini tidak dijual dipasaran. Komponen ini dibuat untuk menyangga sisi bawah Cover penutup agar berdiri pada posisinya.
Komponen ini di desain dengan bentuk yang dapat menjepit Cover dengan Stand menggunakan baut dan mur sebagai penguncinya.

Proses pembuatan penyangga Cover ini dapat dibentuk dengan teknik pengelasan dari beberapa potongan besi pejal serta plat besi yang dibentuk sesuai desain, serta digunakkan juga teknik Drilling untuk membuat lubang baut. Adapun material yang digunakan adalah Carbon Steel yang kuat dan tahan terhadap karat karena memiliki fungsi menopang juga karena sebagian sisinya terdapat pada sisi luar Cover.

\section{$>$ Cover Penutup (Part Number 13)}

Cover penutup ini berfungsi sebagai pelindung nozzle yang mengeluarkan udara panas, seluruh komponen alat ini dan IOP yang sudah dilapisi semen, agar proses pengeringan berjalan maksimal dan tidak terkena air hujan yang dapat mengganggu proses pengeringan IOP.

Untuk proses pembuatan Cover dibuat sendiri dengan bahan material dari Seng. Lembaran seng di potong sesuai desain dan dibending sudut $90^{\circ}$ untuk sisi siku dengan atap, lalu bagian atap nya dibuat melengkung. Cover ini memiliki desain menyatu antara sisi samping dengan atap sehingga memudahkan pemasangan dan tidak terdapat celah sambungan pada sisi atap dan sisi samping agar tidak terjadi kebocoran saat hujan

\section{Komponen yang didapat dari supplier}

\section{$>$ Pipa besi (Part Number 3)}

Pipa besi merupakan tempat menyalurkan udara panas yang dikeluarkan oleh mesin Hot Air Blower sampai dengan menuju nozzle. Material yang digunakan untuk pipa besi adalah Stainless Steel 304L.

\section{$>$ Knee (Part Number 5, 6, 8)}

Knee merupakan penyambung antar pipa besi agar dapat berbelok sesuai dengan desain yang diinginkan. Adapun Knee terbagi menjadi 3 jenis antara lain, Knee dengan sudut $135^{\circ}$ (Part Number 8) yang digunakan untuk menyambung menuju nozzle, Knee dengan sudut belok $90^{\circ}$ (Part Number 5) dan Knee sudut $90^{\circ} \times 2$ ( Part Number 6) yang memiliki belokan secara horizontal $90^{\circ}$ satu kali dan belokan $90^{\circ}$ secara vertikal.

Adapun material yang digunakan untuk masing-masing Knee adalah Stainless Steel 304L.

\section{$>$ Shock (Part Number 2)}

Shock merupakan penyambung antara dua pipa yang sama atau berbeda ukurannya, juga merupakan sambungan dari Hot Air Blower menuju pipa di bagian bawah. Adapun material yang digunakan untuk komponen Shock adalah Stainless Steel 304L. 


\section{Hot Air Blower (Part Number 1)}

Untuk Hot Air Blower yang digunakan sebagai contoh di laporan ini adalah Leister Vulcan System $10 \mathrm{~kW}$, yang memiliki spesifikasi sebagai berikut:

Tabel 2 Spesifikasi Hot Air Blower

\begin{tabular}{|c|c|}
\hline Voltage & $3 \times 230$ Volt \\
\hline Power & 10000 Watt \\
\hline Max Air Outlet Temperature & $650^{\circ} \mathrm{C}$ \\
\hline Pressure & $3.1-4.0 \mathrm{kPa}$ \\
\hline Max Air Flow & $850 \mathrm{Liter} / 1500$ Minutes \\
\hline Noise Emission Level & $65 \mathrm{~dB}(\mathrm{~A})$ \\
\hline Size $(L \times W \times H)$ & $410 \mathrm{~mm} \times 276 \mathrm{~mm} \times 231 \mathrm{~mm}$ \\
\hline Weight & $9.3 \mathrm{~kg}$ \\
\hline Heating Pipe Diameter & $92 \mathrm{~mm}$ \\
\hline
\end{tabular}

Bisa juga digunakan Hot Air Blower tipe lain yang memiliki spesifikasi dan dimensi yang serupa.

$>$ Baut dan mur

Baut dan mur merupakan komponen yang digunakan untuk mengencangkan antar sambungan klem maupun penyangga yang di desain agar dapat dibongkar pasang. Untuk spesifikasinya membutuhkan baut dan mur berukuran M12 (diameter $12 \mathrm{~mm}$ ) yang didapat dari supplier, sedangkan untuk panjang baut disesuaikan dengan kebutuhan antar sambungan dengan spesifikasi diameter yang sama.

\section{Lokasi Pemasangan Alat Pengering IOP}

Untuk lokasi pemasangan alat pengering $I O P$ adalah pada bagian setelah tower $\mathrm{T} 3$ yaitu disepanjang conveyor 403-V yang mengarah menuju Iron Ore Day bin. Penentuan pemasangan pada posisi ini karena faktor kandungan air pada IOP yang sudah di Coating lebih sedikit daripada di conveyor $402-\mathrm{V}$. Hal ini dikarenakan pada tower T3 adanya proses dimana IOP dijatuhkan dari conveyor 402-V ke conveyor 403-V dengan adanya proses pemisahan air, tetapi IOP masih terlalu basah sementara kondisi IOP yang ideal adalah kering sempurna. Oleh karena itu alat pengering ini diletakan pada conveyor 403-V agar IOP dapat kering sempurna sebelum masuk ke Iron Ore Day bin lalu di distribusikan ke reaktor. Pada belt conveyor $403-\mathrm{V}$ akan dipasang alat pengering IOP sejumlah 3 unit, dengan jarak antar unit sekitar 5 meter agar proses pengeringan maksimal.

\section{Penggantian Belt conveyor 403-V}

Penggantian belt conveyor $403-\mathrm{V}$ dilakukan karena proses pengeringan IOP menggunakan temperature yang tinggi, sementara belt conveyor 403-V selama ini menggunakan jenis belt conveyor yang non-heat resistance atau dalam arti tidak tahan terhadap temperature tinggi.
Adapun spesifikasi belt conveyor 403-V yang selama ini digunakan adalah sebagai berikut:

Tabel 3 Spesifikasi Belt Conveyor 403-V nonheat resistance

\begin{tabular}{|c|c|}
\hline Name & $\begin{array}{c}\text { CONVEYOR BELT - EP1250/4- } \\
\text { 1000X4X4MM-M-RMA1 }\end{array}$ \\
\hline Belt Width & $1000 \mathrm{~mm}$ \\
\hline Belt Length & $250000 \mathrm{~mm}$ \\
\hline Type & POL YESTER "EP" \\
\hline Tensile Strength & $1250 \mathrm{kN} / \mathrm{m}$ \\
\hline No. Of Ply & 4 \\
\hline Top Cover Thickness & $4 \mathrm{~mm}$ \\
\hline Bottom Cover Thickness & $4 \mathrm{~mm}$ \\
\hline Belt Thickness Range & $14-15 \mathrm{~mm}$ \\
\hline Cover Material & Grade M "RMA-1" \\
\hline Manufacture & BANDO \\
\hline
\end{tabular}

Dibawah ini adalah spesifikasi pengganti belt conveyor $403-\mathrm{V}$ lama dengan yang memiliki spesifikasi heat-resistance.

Tabel 4 Spesifikasi Belt Conveyor 403-V heat resistance

\begin{tabular}{|c|c|}
\hline Belt Width & $1000 \mathrm{~mm}$ \\
\hline Belt Length & $250000 \mathrm{~mm}$ \\
\hline Type & POLYMER "EPR" \\
\hline Tensile Strength & $1250 \mathrm{kN} / \mathrm{m}$ \\
\hline No. Of Ply & 4 \\
\hline Top Cover Thickness & $5 \mathrm{~mm}$ \\
\hline Bottom Cover Thickness & $3 \mathrm{~mm}$ \\
\hline Belt Thickness Range & $14-15 \mathrm{~mm}$ \\
\hline Cover Material & $\begin{array}{c}\text { Heat- Carry } 710(\mathrm{Max} . \text { temperature of } \\
\left.\text { material handled is about } 400^{\circ} \mathrm{C}\right)\end{array}$ \\
\hline Manufacture & BANDO \\
\hline
\end{tabular}

\section{Analisa Tekanan dan Temperatur Pada Aliran Udara Pada Pipa}

Udara panas yang dikeluarkan oleh Hot Air Blower disalurkan menuju nozzle melalui pipa dan beberapa knee untuk membelokkan aliran udara. Udara panas yang dikeluarkan Hot Air Blower ini dapat diatur temperatur pengeluaran udaranya dengan maksimal temperature adalah $650^{\circ} \mathrm{C}$. Udara panas yang dikeluarkan Hot Air Blower juga memiliki tekanan sebesar $4 \mathrm{kPa}$. Tekanan udara yang dialirkan melalui pipa dan knee pasti mengalami penurunan tekanan udara. 


\section{Simulasi Aliran Tekanan Udara}

Gambar dibawah ini merupakan simulasi aliran tekanan udara yang keluar dari mesin Hot Air Blower melalui pipa dan keluar melalui nozzle.

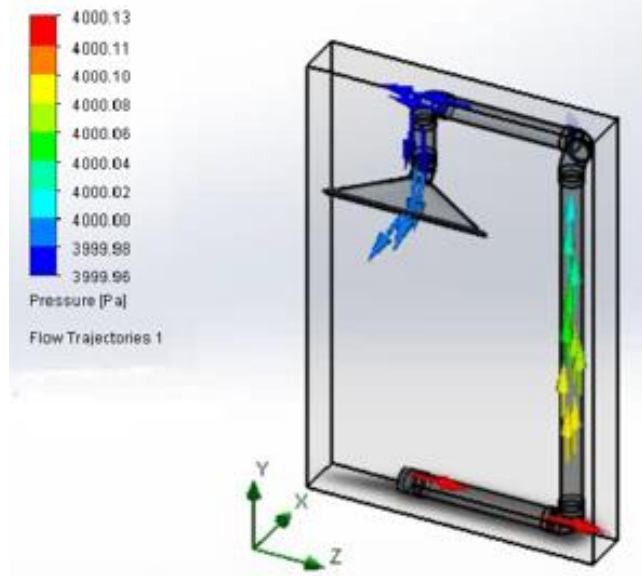

Gambar 5 Simulasi Tekanan udara panas dalam pipa

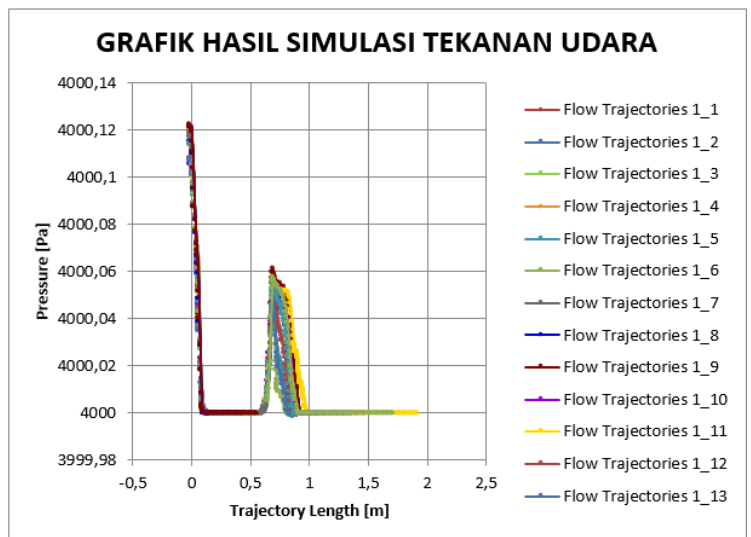

Gambar 5.3 Simulasi Tekanan udara panas dalam pipa

\section{Simulasi Temperatur Aliran Udara}

Temperatur udara yang dikeluarkan oleh mesin Hot Air Blower disesuaikan agar tidak merusak permukaan Belt conveyor, namun tetap dapat mengeringkan IOP. Temperatur udara yang dikeluarkan Hot Air Blower diatur menjadi $120^{\circ} \mathrm{C}$, pada kondisi temperatur ini bertujuan agar IOP yang sudah di Coating menjadi kering karena titik uap air adalah diatas $100^{\circ} \mathrm{C}$. Adapun maksimal panas yang mampu diterima Belt conveyor heat-resistance adalah $400^{\circ} \mathrm{C}$.

Pada setiap pipa dan knee yang dilalui udara panas diberi isolasi agar panas yang keluar sama dengan panas yang dihasilkan oleh Hot Air Blower.

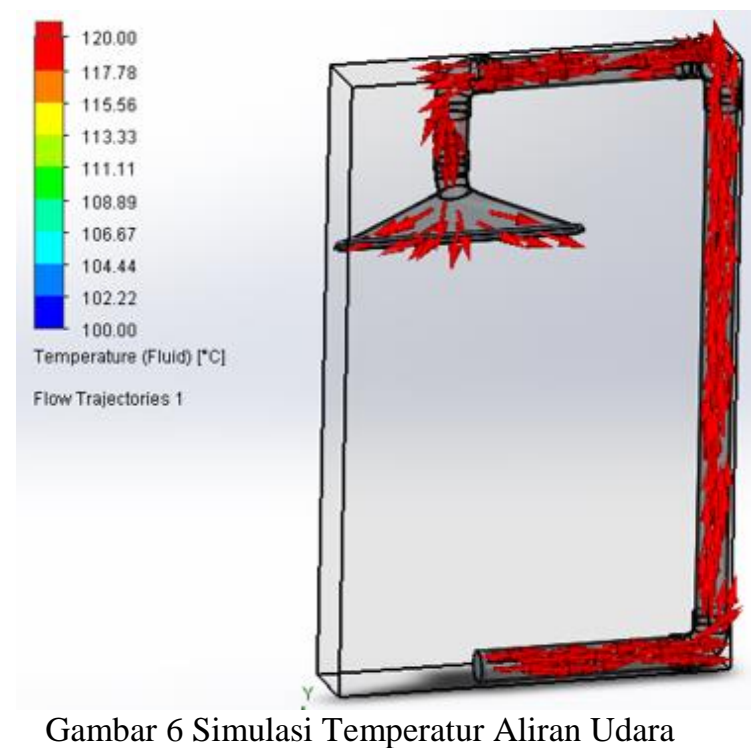

\section{KESIMPULAN}

1. Untuk melancarkan proses material handling, terutama dari proses cement coating sampai IOP masuk iron ore day bin, terlihat bahwa proses pemisahan air dengan IOP yang sudah di coating kurang maksimal, maka perlu dilakukan pengeringan lebih lanjut terhadap IOP yang sudah di coating tersebut.

2. Untuk mencegah adanya penggumpalan IOP yang sudah di coating pada day bin, sistem charging, dan didalam reaktor maka solusi yang dapat diambil yaitu melakukan proses pengeringan lebih lanjut menggunakan alat hot air blower yang sudah dirancang. Adapun indikator untuk menentukan bahwa IOP sudah kering ketika mengaplikasikan alat ini adalah dengan melakukan simulasi temperatur melalui software, dimana temperature keluaran dari hot air blower di atur menjadi 1000C, sehingga kandungan air pada IOP yang sudah di coating dapat menguap semua dan membuat IOP yang sudah di coating menjadi kering.

3. Dengan alat hot air blower yang dirancang untuk mencegah penyumbatan akibat gumpalan IOP yang masih terlalu basah pada sistem charging, maka proses material handling akan memiliki keuntungan yaitu mengurangi frekuensi maintenance.

\section{DAFTAR PUSTAKA}

PT Krakatau Steel. 2000. Iron Ore Handling. Cilegon: PT Krakatau Steel.

Hylsa. 1994. HYL III Process Direct Reduction Plant. Mexico: HYL, Technology Division.

Erinofiardi, E. (2012). Analisa Kerja Belt Conveyor 5857-V Kapasitas 600 Ton/Jam. Rekayasa Mesin, 3(3), 450-458. 
Cahyadi, D., \& Azis, G. F. PERANCANGAN BELT CONVEYOR KAPASITAS 30 TON/JAM UNTUK ALAT ANGKUT KERTAS.

Ramadhan, Rakhmad. 2011. Catalog Bando. Diambil https://www.scribd.com/doc/283529222/201 1-Catalog-Bando (diakses 22 Januari 2019).

Leister Technologies AG. 2018. Leister Hot Air Blower Vulcan System 10kW. Diambil dari https://www.leister.com/en/processheat/products/hot-air-blower/vulcan/vulcansystem-10-kw (diakses 25 Januari 2019).

PT Krakatau Steel (Persero) Tbk. 2018. Sejarah Singkat. Diambil dari http://www.krakatausteel.com/index.php?pa ge $=$ content $\&$ cid $=8 \quad($ diakses 14 Januari 2019).

PT Krakatau Steel (Persero) Tbk. 2018. Fasilitas Produksi. Diambil dari http://www.krakatausteel.com/index.php?pa ge $=$ content $\&$ cid $=47 \quad$ (diakses 14 Januari 2019).5. 